ACTA MYCOLOGICA

Vol. 48 (1): 41-49

2013

DOI: $10.5586 / \mathrm{am} .2013 .006$

\title{
Preliminary study of endophytic fungi in timothy (Phleum pratense) in Estonia
}

\author{
TRIIN VARVAS, KRISTINA KASEKAMP and BELLIS KULLMAN* \\ Department of Mycology, Institute of Agricultural and Environmental Sciences \\ Estonian University of Life Sciences, Kreutzwaldi 5, EE-51014 Tartu \\ *corresponding author: bellis.kullman@emu.ee
}

Varvas T., Kasekamp K., Kullman B.: Preliminary study of endophytic fungi in timothy (Phleum pratense) in Estonia. Acta Mycol. 48 (1): 41-49, 2013.

Timothy (Phleum pratense L.) is an important agricultural grass in Europe and North America, but there is little research into the occurrence and abundance of fungal endophyte species associated with this grass. The aim of this study was to identify fungal endophytes living within $P$. pratense and to determine if additional moisture applied during the growing season increases the diversity of endophytic fungi. We studied 58 isolates obtained from surfacesterilised blades of 60 P. pratense plants collected from Rõka Free Air Humidity Manipulation experimental plots (FAHM), Estonia. Morphological and molecular methods were used for isolate identification. As a result, 45 strains from 10 different taxa were identified, all belonging to Ascomycota. Five species were found to be new to P. pratense.

Key words: agricultural grasses, endophytes, isolate identification, ITS, FAHM

\section{INTRODUCTION}

Plants and fungi commonly have a mutualistic relationship and, in the case of endophytes, they reside inside plant tissue, mostly without causing disease (Carroll 1988; Clay, Schardl 2002). Sometimes impact from the environment can make these fungi parasitic or pathogenic to host plants (Schardl et al. 1997; Meijer, Leuchtmann 1999; Schulz et al. 1999; Kogel et al. 2006; Johnson, Oelmüller 2009). Most of them are non-specific regarding their host preference (Petrini 1986; Saikkonen et al. 1998; Arnold et al. 2000) and can live together with other endophytes in the same host (An et al. 1992; Saikkonen et al. 1998; Arnold et al. 2000), holding greater promise for plant growth promotion and increased yield in agriculturally important grasses.

Endophyte presence in plants has also been shown to help them deal with prolonged periods of drought, excess moisture or light (Bouton et al. 1993; Bier 1995; Marks, Clay 1996; Lewis et al. 1997; Cheplick et al. 2000; Malinowski, Belesky 2000). 
Increases in biomass and tolerance to attack from herbivores and insects are often ascribed to endophytes (Bacon, Hill 1996; Clay and Holah 1999; Sahay, Varma 1999; Redman et al. 2001; Arnold et al. 2003; Waller et al. 2005; Márquez et al. 2007).

P. pratense is a widespread arable crop that is, however, poorly investigated in terms of its endophytic fungal diversity. The purpose of our study was to identify fungal endophytes living inside the leaves of $P$. pratense and to determine if differences in water treatments in the FAHM experimental area affect the diversity of endophytes.

\section{MATERIALS AND METHODS}

Sampling plant material and endophyte isolation. Samples were collected on 29 October 2008 from Free Air Humidity Manipulation (FAHM) experimental plots at Rõka, Tartu County, in southeast Estonia (58 $\left.14^{\circ} 44^{\prime \prime N}, 27^{\circ} 17^{\prime} 58^{\prime \prime E}\right)$. Plants were collected from four plots with additional moisture being applied to the plots (H1-H4) and from two control plots without additional water being applied (C1 and $\mathrm{C} 4)$. In one plot, $\mathrm{H} 3$, there appeared a problem with the watering system and it could not be used in comparison. Altogether, 60 P. pratense plants were collected.

Immediately after collection, one to two $P$. pratense leaves were separated from the plants and cut into $5 \times 5 \mathrm{~mm}$ fragments. The surfaces of the fragments were disinfected by rinsing in $96 \%$ ethanol for $1 \mathrm{~min}$, followed by repeated rinsing in sterile water. Fragments were placed in Petri dishes $(9 \mathrm{~cm}$ diam.) on potato dextrose agar (PDA, Merck KGaA Germany) supplemented with tetracycline and streptomycin $(50 \mu \mathrm{l}$ each per $\mathrm{ml})$ for suppression of bacterial growth. Petri dishes were examined for mycelial growth for 30 days and all fungal growth was subcultured on individual PDA plates with antibiotics for subsequent identification. For molecular identification, 7-10 days after inoculation of subcultures, a $5 \times 5 \mathrm{~mm}$ piece of mycelium with agar was cut and preserved in sodium dodecyl sulphate (SDS).

Endophyte identification by morphology. Morphological characterization relied on the colour, appearance, growth rate and microscopical hyphal features of endophytic colonies. Similar cultures were grouped together based on morphotype and the main characteristics were analysed for representatives of these groups. Growth rate was measured for 23 days. Image Pro Plus 6.0 program was used to calculate the area occupied by mycelium.

Colony colour was determined at approximately 17 days using the Methuen Handbook of Colour (Kornerup, Wanscher 1967). Both surface and reverse colours were recorded and in case of more than one dominant colour, all were recorded (data not shown). Colony colour was determined by viewing the isolates in daylight. The colour of the medium and the occurrence of aerial mycelium were also noted if present. Morphological descriptions were made in sterile water using a Zeiss Axioskop 40 FL microscope, an AxioCam MRc camera and the Axio Vison 1.6 program. Species determination followed taxonomic monographs and manuals (Domsch et al. 1980; Ellis, Ellis 1997; Leslie, Summerell 2006). Vouchers strains were deposited in the Collection of fungal living cultures [TFC 2010-001 - TFC 2010-035] at the Estonian University of Life Sciences. 
Endophyte identification by molecular methods. Genomic DNA was extracted from pure cultures using Genomic DNA Purification Kit K0512 (Fermentas) and stored in CTAB buffer according to Gardes and Bruns (1993). ITS regions of rDNA were amplified by PCR using primers ITS1F (5' to 3': CTT GGT CAT TTA GAG GAA GTA A) and ITS4 (5' to $3^{\prime}$ : TCC TCC GCT TAT TGA TAT GC) using a Biometra TProfessional Basic Thermocycler (Biometra $\mathrm{GmbH}$, Germany) with 35 cycles of 30 $\mathrm{s}$ at $95^{\circ} \mathrm{C}$ (denaturing), $30 \mathrm{~s}$ at $55^{\circ} \mathrm{C}$ (annealing), and $1 \mathrm{~min}$ at $72^{\circ} \mathrm{C}$ (extension).

The resulting PCR product was purified with Exo-Sap (Fermentas) following manufacturer's instructions. Samples were sequenced in Macrogen (Korea) with primers ITS1 5` to $3^{`}:$ TCC GTA GGT GAA CCT GCG G and ITS5 5` to 3`: GGA AGT AAA AGT CGT AAC AAG G. Sequences were edited using the program Sequence Scanner 1.0 (Applied Biosystems, Foster City, California, USA). Sequences obtained from 45 cultures were compared with the ones in GenBank using BLASTn algorithm. Sequences that were more than $97 \%$ identical were considered to be homospecific. Colonization frequency ( $\mathrm{CF} \%$, the percentage of plants colonized) was calculated by using the formula: $\mathrm{CF}=(\mathrm{Ncol} / \mathrm{Nt}) \times 100$, where, $\mathrm{Ncol}$ is the number of segments colonized by each endophyte and $\mathrm{Nt}$ is the total number of segments observed (Hata, Futai 1995).

\section{RESULTS}

In total, 58 endophyte strains were isolated from the 60 plants. Of these, 45 isolates were identified by sequence analysis of the ITS region. These isolates belonged to 10 taxa based on sequence data ITS: Alternaria arbusti E.G. Simmons, Lewia viburni E.G. Simmons (anamorph Alternaria viburni E.G. Simmons), Apiospora montagnei Sacc. (anamorph Arthrinium arundis (Corda) Dyko et B. Sutton), Aureobasidium pullulans (de Bary) G. Arnaud, Epicoccum nigrum Link, Fusarium sp., Gibberella avenacea R.J. Cooke (anamorph Fusarium avenaceum (Fr.) Sacc.), Monographella sp., Paraphaeosphaeria michotii (Westend.) O.E. Erikss. and Phaeosphaeria herpotrichoides (De Not.) L. Holm (Fig. 1.). Species determinations using GenBank references are given in Table 1. Colonization frequency of isolated fungi is shown on Figure 2.

Morphological studies were performed for most isolates, but only $33 \%$ of them resulted in determination of species or genus, while others remained sterile. Morphological studies allowed identification of six species or genera; $A$. pullulans, $E$. nigrum, F. sporotrichioides, F. avenaceum, Arthrinium sp. and Alternaria sp. (Fig. 1). A plant sample usually contained only one fungal species, although two of the samples gave two different species each (E. nigrum and $A$. arbusti, E. nigrum and $P$. herpotrichioides). In morphological analyses, $67 \%$ of cultures were sterile and for these ITS analysis and morphotype concept (Guo et al. 2000; Arnold et al. 2003) was used to determine species.

Growth rates had noticeable variation both between species $(0.08-0.71 \mathrm{~cm} / \mathrm{day})$ and also within species. Growth rate within the $E$. nigrum group was $0.10-0.26 \mathrm{~cm} /$ day. Average growth rate for all species combined was $0.25 \mathrm{~cm}$ per day, with $A$. pullulans having the lowest (0.08) and $A$. montagne the highest (0.71) radial growth. 
Table 1

Endophytic fungi isolated based on sequence comparison to GenBank database

\begin{tabular}{|c|l|c|}
\hline Isolate & \multicolumn{1}{|c|}{ Species } & GenBank accession no. \\
\hline H4-8-2 & Phaeosphaeria herpotrichoides & JN688915 \\
\hline H3-8-3 & Apiospora montagnei & JN688916 \\
\hline C1-7 & Aureobasidium pullulans & JN688917 \\
\hline C1-6 & Epicoccum nigrum & JN688918 \\
\hline C1-4-3 & Alternaria arbusti & JN688919 \\
\hline H3-6-1 & Fusarium avenaceum & JN688920 \\
\hline H4-4-1 & Alternaria viburni & JN688921 \\
\hline C1-9-1 & Fusarium sporotrichioides & JN688922 \\
\hline C4-7 & Monographella sp. & JN688923 \\
\hline C1-3-3 & Paraphaeosphaeria michotii & JN688924 \\
\hline
\end{tabular}

The results of our study showed that the diversity of endophytes was not higher in the experimental plots with additional water given to the plants during the growing season. In fact, both the highest number of isolates (plot H4, 15 isolates) and the lowest number of isolates (plot H1, 5) were obtained from plots with applied additional moisture. In average, 11 isolates were obtained from each control plot and 9 isolates were obtained from each experimental plot. Considering these results, the positive effect of extra moisture on the diversity of endophytic fungi was not established.

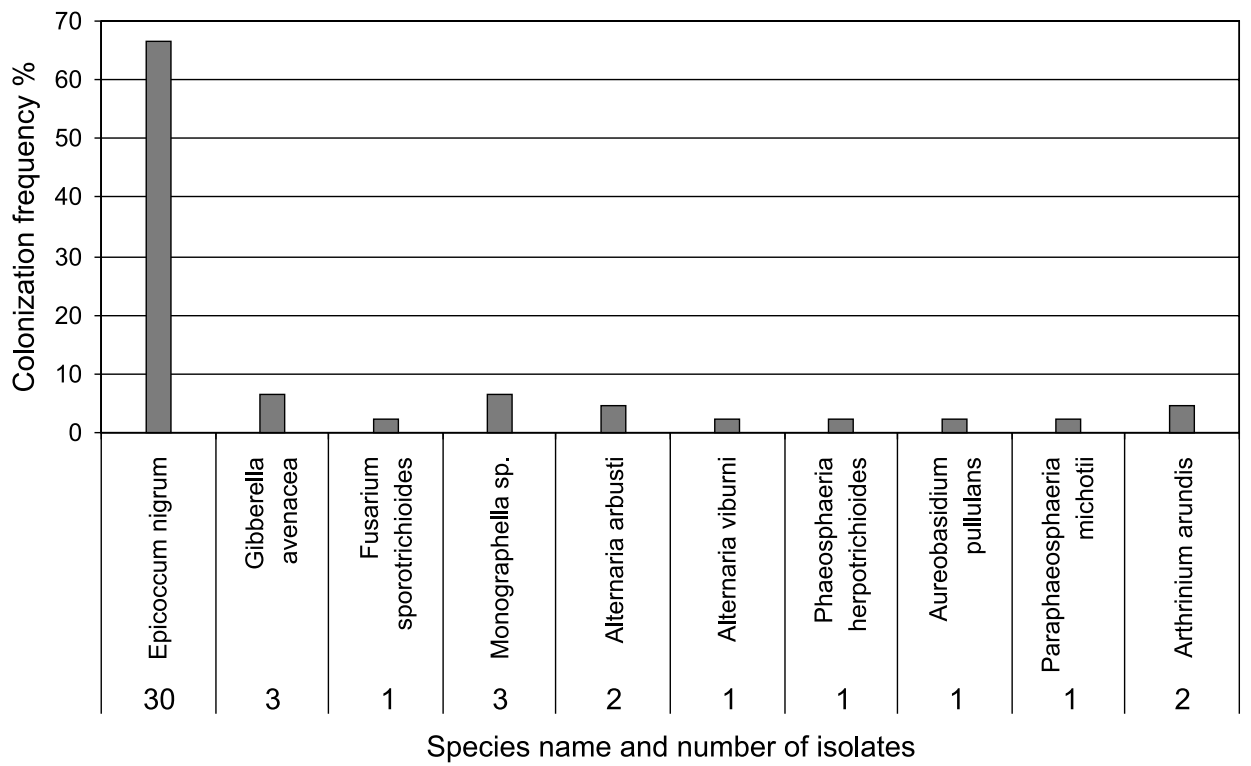

Fig. 2. Identified species and their colonization frequency (CF\%). 

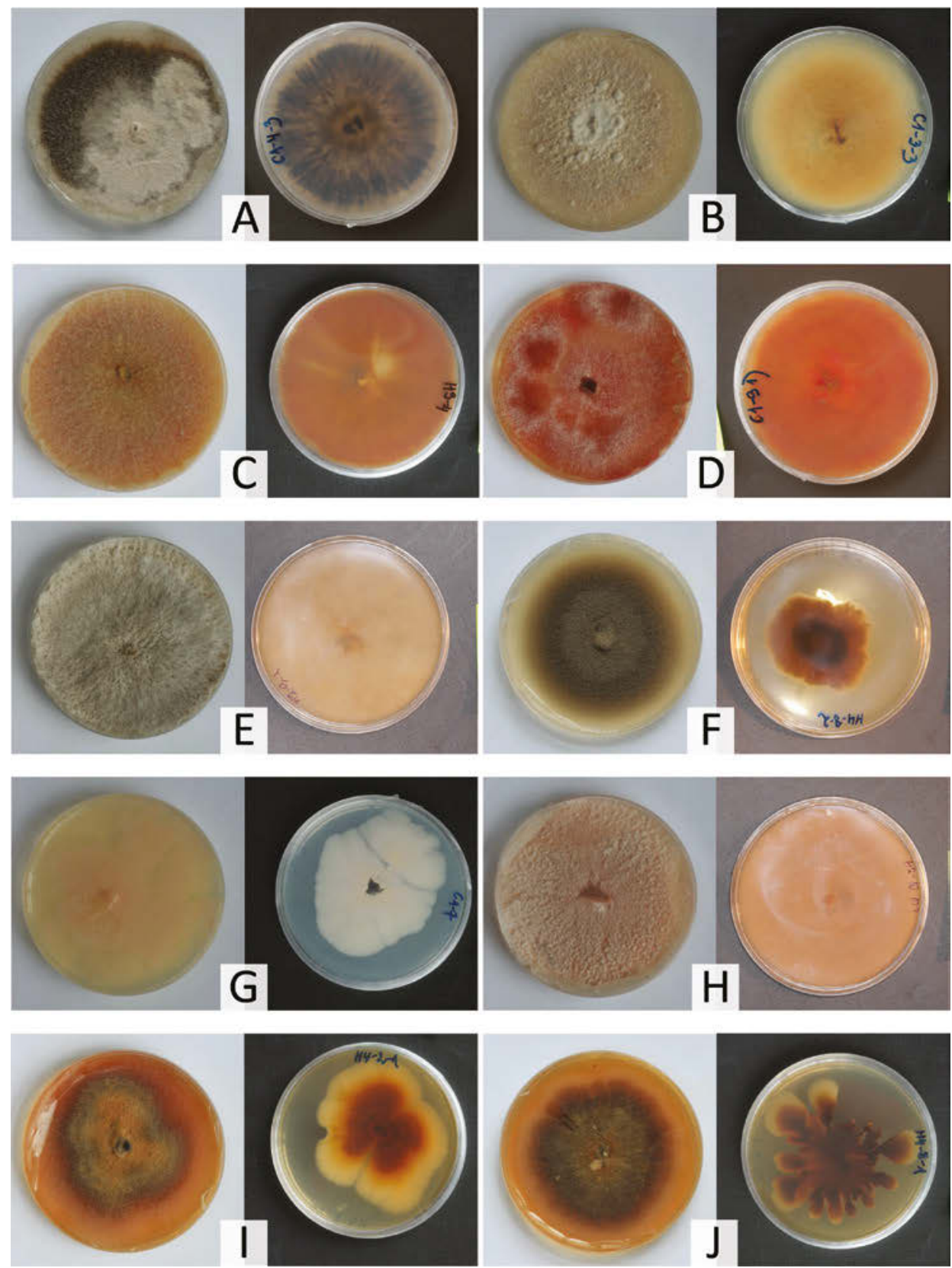

Fig. 1. Photographs of fungal cultures (surface and reverse): A - Alternaria arbusti, B - Phaeosphaeria herpotrichoides, C - Gibberella avenacea (Fusarium avenaceum, D - Fusarium sporotrichioides, E - Apiospora montagnei (Arthrinium arundis), F - Paraphaeosphaeria michotii, $\mathrm{G}$ - Aureobasidium pullulans, H - Monographella sp., I - Epicoccum nigrum, J - Epicoccum nigrum, Lewia viburni (Alternaria viburni) photograph not included. 


\section{DISCUSSION}

This study of the endophytes of $P$. pratense, a temperate perennial grass, resulted in the identification of 45 strains from 10 different taxa. According to previous research, the presence of endophytes can be higher in tropical plants (Arnold, Lutzoni 2007), approaching $100 \%$. In plants from colder climates the endophyte diversity is much lower (Rosa et al. 2009). The rate of endophytes is also dependent on environmental conditions. Results from Zamora et al. (2008) suggest that the season, isolation method and tissue health decisively affected the frequency and species distribution of endophytes. Almost all species isolated in Zamora et al. (2008) work were recovered in autumn and nearly half of these exclusively during this season.

The fungal endophytes associated with $P$. pratense have previously been investigated mostly within large scale studies along with other species and in relation to their toxicity to animals, differences in infection rates in natural and cultural communities and diversity (Bacon, Hill 1996; Clay, Holah 1999; Sahay, Varma 1999; Redman et al. 2001; Arnold et al. 2003; Waller et al. 2005; Márquez et al. 2007).

Earlier studies have found, from P. pratense, mainly Ascomycota, but also Basidiomycota, Blastocladiomycota, Chytridiomycota and Zygomycota (Waipara et al. 1996; Ellis, Ellis 1997; Sanchez Marquez et al. 2010). These species range from saprobes to pathogens, but some might turn out to be endophytes as well. It is sometimes difficult to differentiate between pathogens and parasites or epiphytes and endophytes. Transitions may occur between these types (Redlin, Carris 1996; Azevado 1998). Most research concerning $P$. pratense has so far dealt mostly with pathogens, epiphytes and saprobes. For a complete list of previously described fungi connected with P. pratense see the following resources: NewCROP (http://www.hort. purdue.edu/newcrop/duke_energy/Phleum_pratense.html), Ellis and Ellis (1997), Ing (1990). Some of these species are known to have only one type of association with the host plant, while others have been found to be either epiphytic, endophytic, saprotrophic or pathogenic, depending on the host plant. This suggests that the type of association is not always constant and depends on many variables.

All of the 10 endophytes identified in this study belong to Ascomycota, four of which were anamorphs for whom teleomorphs connections are unknown or not recorded according to Index Fungorum (www.indexfungorum.org). These are $A$. arbusti, $A$. pullulans, E. nigrum and $F$. sporotrichioides. P michotii, $P$. herpotrichoides, and mostly also Monographella sp. teleomorphs connections with anamorphs are problematic and mostly unknown or not recorded. Only three of our species have known connections between tele- and anamorphs: $A$. montagne $i$ is associated with $A$. arundinis, G. avenacea with $F$. avenaceum and $L$. viburni with $A$. viburni.

In terms of abundance, we found in our study, that E. nigrum was the dominating species (colonizing frequency $67 \%$ of all isolates (Fig. 2). When one plant sample was shown to have more than one endophyte, E. nigrum was always present. Sanchez Marquez et al. (2010) also referred to the high domination rate of Holcus lanatus L. by Epicoccum, Alternaria and Aureobasidium.

In terms of fungal diversity based on different water treatments, no definite positive effect of additional water availability was observed. 


\section{CONCLUSIONS}

The aim of this study was to identify fungal endophytes living inside the leaves of $P$. pratense.

As a result, 45 strains from 10 different taxa were identified. Half of the taxa isolated in this study - A. pullulans, E. nigrum, G. avenacea, Monographella sp., and $P$. herpotrichoides - had been identified from timothy earlier as endophytes (Salkin et al. 1986; Domch et al. 1993; Huang et al. 2008; Osono 2008; Tao et al. 2008; Dodd 2010;). A. arbusti, L. viburni, A. montagnei, F. sporotrichioides and P. michotii are new endophytic fungi isolated from timothy. Two of these, A. arbusti and L. viburni, are also new species to Estonia (Varvas, Kullman 2012).

To obtain a better insight into the communities of blade endophytes, in situ molecular techniques should be used for unculturable and slowly growing fungal taxa. In particular, 454 sequencing allows to identify of hundreds of species using a large number of samples (Jumpponen, Jones 2009).

Acknowledgements. The research was supported from the project "Plant protection for sustainable crop production" SF0170057s09. We thank Dr. Leho Tedersoo (Institute of Ecology and Earth Sciences, University of Tartu) for useful consultations and help. Our sincere thanks are due to Mrs. E. Jaigma for revising the English text of the manuscript.

\section{REFERENCES}

An Z.Q., Liu J.S., Siegel M.R., Bunge G., Schardl C.L. 1992. Diversity and origins of endophytic fungal symbionts of the North American grass Festuca arizonica. Theor. Appl. Genet. 85: 366-371.

Arnold A.E., Maynard Z., Gilbert G.S., Coley P.D., Kursar T.A. 2000. Are tropical endophytes hyperdiverse? Ecol. Let. 3: 267-274.

Arnold A.E., Mejia L.C., Kyllo D., Rojas E., Maynard Z., Robbins N., Herre E.A. 2003. Fungal endophytes limit pathogen damage in a tropical tree. Proc. Natl. Acad. Sci. USA 100: 15649-15654.

Arnold A.E., Lutzoni F. 2007. Diversity and host range of foliar fungal endophytes: are tropical leaves biodiversity hotspots? Ecology 88: 541-549.

Azevedo J.L. 1998. Microorganismos endofíticos. Ecologia Microbiana, EMBRAPA, Jaguariuna.

Bacon C.W., Hill N.S. 1996. Symptomless grass endophytes: products of coevolutionary symbioses and their role in the ecological adaptations of grasses. (In:) S.C. Redlin, L.M. Carris (eds). Endophytic fungi in grasses and woody plants: systematics, ecology, and evolution. APS Press, St Paul, MN, pp $155-178$.

Bier J. 1995. Relationship between transmission mode and mutualism in the grass-endophyte system. Dissertation, Indiana University.

Bouton J.H., Gates R.N., Belesky D.P., Owsley M. 1993. Yield and persistence of tall fescue in the southeastern coastal plain after removal of its endophyte. Agron. J. 85: 52-55.

Carroll G.C. 1988. Fungal endophytes in stems and leaves: from latent pathogen to mutualistic symbiont. Ecology 69: 2-9.

Cheplick G.P., Perera A., Koulouris K. 2000. Effect of drought on the growth of Lolium perenne genotypes with and without fungal endophytes. Funct. Ecol. 14: 657-667.

Clay K., Holah J. 1999. Fungal endophyte symbiosis and plant diversity in successional fields. Science 285: $1742-1745$.

Clay K., Schardl C. 2002. Evolutionary Origins and Ecological Consequences of Endophyte Symbiosis with Grasses. Am. Nat. 160: S99-S127. 
Dodd S., Ganley R., Bellgard S., Than D. 2010. Endophytes associated with Cirsium arvense - a step toward understanding their role in the success/failure of Sclerotinia sclerotiorum as a bioherbicide. (In.) S. M. Zydenbos (ed.) Proceedings of the 17th Australasian Weeds Conference, Christchurch, New Zealand 26-30 Sept 2010: 235-238.

Domsch K.H., Gams W., Anderson T.H. 1980. Compendium of soil fungi. IHW-Verlag, Eching, Germany.

Domsch, K.H., Gams W., Anderson T.H. 1993. Compendium of soil fungi. IHW-Verlag, Eching, Germany.

Ellis M.B., Ellis J.P. 1997. Microfungi on Land Plants. An Identification Handbook. Richmond Publishing, Slough.

Gardes M., Bruns T.D. 1993. ITS primers with enhanced specificity for basidiomycetes - application to the identification of mycorrhizae and rusts. Mol. Ecol. 2: 113-118.

Guo L.D., Hyde K.D., Liew E.C.Y. 2000. Identification of endophytic fungi from Livistona chinensis based on morphology and rDNA sequences. New Phytol. 147 (3): 617-630. http://dx.doi.org/10.1046\%2Fj.1469-8137.2000.00716.x

Hata K., Futai K. 1995. Endophytic fungi associated with healthy pine needles and needles infested by the pine needle gall midge Thecodiplosis japonensis. Can. J. Bot. 73: 384-390.

Huang W.Y., Cai Y.Z., Hyde K.D., Corke H., Sun M. 2008. Biodiversity of endophytic fungi associated with 29 traditional Chinese medicinal plants. Fungal Divers. 33: 61-75.

Ing B. 1990. An introduction to British powdery mildews. The Mycologist 4: 46-48.

Johnson J.M., Oelmüller R. 2009. Mutualism or parasitism: life in an unstable. What can we learn from the mutualistic interaction between Piriformospora indica and Arabidopsis thaliana? Endocyt. Cell. Res. 19: 81-111.

Jumpponen A., Jones K.L. 2009. Massively parallel 454 sequencing indicates hyperdiverse fungal communities in temperate Quercus macrocarpa phyllosphere. New Phytol. 184: 438-448. http://dx.doi.org/10.1111\%2Fj.1469-8137.2009.02990.x

Kogel K.H., Franken P., Hückelhoven R. 2006. Endophyte or parasite - what decides? Curr. Opin. Plant. Biol. 9: 358-363.

Kornerup A., Wanscher J.H. 1967. Methuen Handbook of Colour. 2nd ed. Methuen and Co. Ltd, London.

Leslie J.F., Summerell B.A. 2006. The Fusarium Laboratory Manual. Blackwell Publishing Ltd, Oxford.

Lewis G.C., Ravel C., Naffaa W., Astier C., Charmet G. 1997. Occurrence of Acremonium endophytes in wild populations of Lolium spp. in European countries and a relationship between level of infection and climate in France. Ann. Appl. Biol. 130: 227-238.

Malinowski D.P., Belesky D.P. 2000. Adaptations of endophyte-infected cool-season grasses to environmental stresses: mechanisms of drought and mineral stress tolerance. Crop. Sci. 40: 923-940.

Marks S., Clay K. 1996. Physiological responses of Festuca arundinacea to fungal endophyte infection. New Phytol. 133: 727-733. http://dx.doi.org/10.1111\%2Fj.1469-8137.1996.tb01941.x

Márquez L.M., Redman R.S., Rodriguez R.J., Roossinck M.J. 2007. A virus in a fungus in a plant-three way symbiosis required for thermal tolerance. Science 315: 513-515.

Meijer G., Leuchtmann A. 1999. Multistrain infections of the grass Brachypodium sylvaticum by its fungal endophyte Epichloë sylvatica. New Phytol. 141: 355-368. http://dx.doi.org/10.1046\%2Fj.1469-8137.1999.00332.x

New Crop Resource Online Program. Purdue University Center for New Crops and Plant Products, Indiana, USA. http://www.hort.purdue.edu/newcrop/duke_energy/Phleum_pratense.html. Accessed: 11 February 2010.

Osono T. 2008. Endophytic and epiphytic phyllosphere fungi of Camellia japonica: seasonal and leaf agedependent variations. Mycologia 100: 387-391. http://dx.doi.org/10.3852\%2F07-110R1

Petrini O. 1986. Taxonomy of endophytic fungi of aerial plant tissues. (In:) N.J Fokkema, J. van den Heuvel (eds). Microbiology of the phyllosphere. Cambridge University Press, Cambridge, pp. 175-187.

Redlin S.C., Carris L. M. 1996. Endophytic fungi in grasses and woody plants. APS Press, The American Phytopathological Society Press, St. Paul, MN.

Redman R.S., Dunigan D.D., Rodriguez R.J. 2001. Fungal symbiosis: from mutualism to parasitism, who controls the outcome, host or invader? New Phytol. 151: 705-716. http://dx.doi.org/10.1046\%2Fj.0028646x.2001.00210.x

Robert V., Stegehuis G., Stalpers J. 2005. The MycoBank engine and related databases. http://www.mycobank.org. Accessed 18 July 2009. 
Rosa L.H., Vaz A.B.M., Caligiorne R.B., Campolina S., Rosa C.A. 2009. Endophytic fungi associated with the Antarctic grass Deschampsia antarctica Desv. Polar Biol. 32: 161-167. http://dx.doi.org/10.1007\%2Fs00300-008-0515-z

Sahay N.S., Varma A. 1999. Piriformospora indica: a new biological hardening tool for micropropagated plants. FEMS Microbiol. Lett. 181: 297-302.

Saikkonen K., Faeth S.H., Helander M., Sullivan T.J. 1998. Fungal endophytes: a continuum of interactions with host plants. Ann. Rev. Ecol. Syst. 29: 319-343.

Salkin I.F., Martinez J.A., Kemna M.E. 1986. Opportunistic infection of the spleen caused by Aureobasidium pullulans. J. Clin. Microbiol. 23: 828-31.

Sanchez Marquez S., Bills G.F., Domínguez Acuña L., Zabalgogeazcoa I. 2010. Endophytic mycobiota of leaves and roots of the grass Holcus lanatus. Fungal Divers. 41-1: 115-123.

Schardl C.L., Leuchtmann A., Chung K.R., Penny D., Siegel M.R. 1997. Coevolution by common descent of fungal symbionts (Epichloë spp.) and grass hosts. Mol. Biol. Evol. 14: 133-143. http://dx.doi.org/10.1093\%2Foxfordjournals.molbev.a025746

Schulz B., Römmert A. K., Dammann U., Aust H.J., Strack D. 1999. The endophyte-host interaction: a balanced antagonism. Mycol. Res. 103: 1275-1283. http://dx.doi.org/10.1017\%2FS0953756299008540

Tao G., Liu Z.Y., Hyde K.D., Lui X.Z., Yu Z.N. 2008. Whole rDNA analysis reveals novel and endophytic fungi in Bletilla ochracea (Orchidaceae). Fungal Divers. 33: 101-122.

Varvas V., Kullman B. 2012. First records of two ascomycetes on Phleum pratense in Estonia. Folia Crypt. Est. 49: 73-76.

Waipara N.W., di Menna M.E., Cole A. L.J., Skipp R.A. 1996. Potential pathogenicity of pasture plant root-colonising fungi to seedlings of legumes and grasses. New Zealand: 212-215.

Waller F., Achatz B., Baltruschat H. 2005. The endophytic fungus Piriformospora indica reprograms barley to salt-stress tolerance, disease resistance, and higher yield. Proc. Natl. Acad. Sci. USA 102: 13386-13391.

Zamora P., Martínez-Ruiz C., Diez J.J. 2008. Fungi in needles and twigs of pine plantations from northern Spain. Fungal Divers. 30: 171-184. 